\title{
Imazaquin sorption in surface and subsurface soil samples
}

\author{
Maurílio Fernandes de Oliveira( ${ }^{(1)}$, Hélio Teixeira Prates ${ }^{(1)}$, Derli Prudente Santanna(1) \\ and Rubem Silvério de Oliveira Júnior ${ }^{(2)}$
}

\begin{abstract}
(1)Embrapa Milho e Sorgo, Rod. MG 424, Km 65, Caixa Postal 151, CEP 35701-970 Sete Lagoas, MG, Brasil. E-mail: maurílio.oliveira@cnpms.embrapa.br, htprates@cnpms.embrapa.br, derli@cnpms.embrapa.br (2)Universidade Estadual de Maringá, Dep. de Agronomia, Av. Colombo, no 5.790, CEP 87020-900 Maringá, PR, Brazil. E-mail: rsojunior@uem.br
\end{abstract}

\begin{abstract}
The objective of this work was to study the sorption and desorption of imazaquin, in surface and subsurface soil samples from Brazil. Sorption and desorption steps were carried out using batch equilibration and high performance liquid chromatography analytical routines. The value of $\mathrm{K}_{\mathrm{f}, \mathrm{ads}}$ was positively correlated with clay content, and negatively correlated with $\mathrm{pH}$ of supernatant. Samples from Typic Haplustox, clayey soil profile having high clay content, provided higher $\mathrm{K}_{\mathrm{f}, \mathrm{ads}}$ values, and negative correlation with organic carbon, silt content, cation exchange capacity and $\mathrm{pH}$.
\end{abstract}

Index terms: retention, desorption, oxisol, sustainability.

\section{Sorção do imazaquin em amostras de solos superficiais e subsuperficiais}

\begin{abstract}
Resumo - O objetivo deste trabalho foi estudar a sorção e dessorção do herbicida imazaquin em amostras de solos brasileiros, superficiais e subsuperficiais. Para os ensaios de sorção e dessorção, utilizou-se metodologia de equilíbrio de partição e quantificação por cromatografia líquida de alto desempenho. Os valores de $\mathrm{K}_{\mathrm{f}, \mathrm{ads}}$ foram positivamente correlacionados com os teores de argila, e negativamente correlacionados com o pH do sobrenadante. Para as amostras do Latossolo Vermelho férrico textura argilosa, maiores teores de argila acarretaram maiores valores de $\mathrm{K}_{\mathrm{f}, \mathrm{ad}}$, e a correlação com carbono orgânico, silte, capacidade de troca catiônica e pH foi negativa.
\end{abstract}

Termos para indexação: retenção, dessorção, latossolos, sustentabilidade.

\section{Introduction}

The sustainable use of a soil should be based on the knowledge of its mineralogical, morphological, physical, chemical and biological characteristics, and also on its interactions with chemicals. The fate of chemicals in tropical soils has only recently been the subject of systematic research (Racke et al., 1997), and only in a limited number of countries. In Brazil, herbicides are the most important class of pesticides, representing $55-60 \%$ of the total annual comsumption of agrochemicals (Inoue, 2002).

Imazaquin is an imidazolinone herbicide widely used as a selective soil-applied herbicide for broadleaf weed control in soybean in Brazil. In general, the behavior of imidazolinones in soil is strongly affected not only by $\mathrm{pH}$ (Oliveira Júnior et al., 2001; Regitano et al., 2001), but also by organic carbon (OC) content and soil texture (Regitano et al., 2001), mineralogy (Regitano et al., 1997; Rocha et al., 2003) and water retention (Regitano et al., 2002).
Imazaquin has a unique group of acid-base properties, due to the presence of carboxylic and quinoline groups in its structure, which are both ionizable. Several factors such as speciation, soil-solution and sorbent-surface $\mathrm{pH}$, charge, ionic strength, and solution composition must be considered due to its amphoteric nature, in order to successfully predict sorption by soil (Regitano et al., 1997, 2001; Rocha et al., 2003).

Imazaquin speciation is the main factor influencing sorption by soil. Soil pH influences both sorption and herbicide activity, because it affects the ionic character of soil, of organic matter and clay. At the most common $\mathrm{pH}$ range for tropical soils (pH 5.0-6.5), imazaquin behaves predominantly as an organic anion in a 99\% ionized form (Lee et al., 1990), causing low sorption by soil colloids, which are also negatively charged at this $\mathrm{pH}$ range. However, organic matter $\left(\mathrm{pK}_{\mathrm{a}} \sim 5.2\right)$ can react with polivalent cations, forming chelates or ionic bridges with acid herbicides decreasing $\mathrm{pH}$ effect (Renner et al., 1988). As the $\mathrm{pH}$ decreases, imazaquin 
achieves the neutral form, which increases its sorption to soil organic matter, through hydrophobic interactions. However, this fenomenon has been observed mainly in soils from temperate areas, where organic matter plays important rule on imazaquin sorption. At very low $\mathrm{pH}$ values (lower than the $\mathrm{pK}_{\mathrm{a}}$ value), protonation of quinoline group may occur, resulting in a molecule that is able to form cationic bonds with soil particles (Regitano et al., 2001; Rocha et al., 2002), especially with negatively charged minerals such as iron and aluminum oxides in oxisols.

Sorption of imazaquin increased with $\mathrm{pH}$ variation from 8 to 3, and soil sorption capacity of soil was not reached at pH 3 (Renner et al., 1988). The increase in imazaquin sorption under acidic conditions is attributed to positively charged molecule bonds with the soil, especially, pH dependent minerals, such as kaolinite and iron/aluminum oxides (Regitano et al., 1997). In Brazil, the acric soils group comprehend the end point of the weathering scale and can have a net positive charge in the B horizon (Alleoni \& Camargo, 1995), due to low organic matter and to high $\mathrm{Fe}$ and $\mathrm{Al}$ oxides. In these soils, the values of point of zero salt effect (PZSE) - the $\mathrm{pH}$ value where the sum of the negative and positive charges on the soil surfaces is equal to zero - are higher than those of the temperate soils, and even higher in subsurface horizons. However, weakly sorbed molecules at neutral or alkaline $\mathrm{pH}$ may represent a potential leacher in soil. In this case, leaching may transfer the herbicides to deeper soil layers with different properties, as compared to surface layers. Variations in soil properties with depth can affect retention, movement, and degradation of herbicides (Felding, 1997; Jenks et al., 1998).

The objective of this study was to measure the sorption and desorption behaviour of imazaquin, by a range of surface and subsurface Brazilian soils.

\section{Material and Methods}

Soils in this study were collected from $0-15 \mathrm{~cm}$ depth, air dried, and passed through a $2 \mathrm{~mm}$ sieve. According to Sociedade Brasileira de Ciência do Solo, soils are classified as: Latossolo Vermelho distrófico textura média (quartzipsammentic Haplustox, DRm), Latossolo Vermelho distroférrico textura argilosa (Clayey Rhodic Haplustox, PL) and Gleissolo Háplico textura média (quartzipsammentic Aeric Fluvaquent, HG). These soils, considered as standards by Brazilian Environmental Agency (Ibama), were collected in the Universidade de São Paulo, campus “Luiz de Queiroz”, in Piracicaba, SP. The fourth sampled soil was a Latossolo Vermelho férrico (Typic Haplustox, THx), collected from Embrapa National Maize and Sorghum Research Center (Embrapa Milho e Sorgo), located at Sete Lagoas, MG, Brazil. For this specific site, a soil profile was sampled every $15 \mathrm{~cm}$, from top, down to $120 \mathrm{~cm}$ depth.

Selected chemical, physical and mineralogical attributes of soil samples are listed in Table 1: organic carbon (OC) content was determined by the WakleyBlack method (Nelson \& Sommers, 1982); pH by a 1:2 soil:water ratio; soil texture was determined by the hydrometer method (Gee \& Bauder, 1986); and soil moisture by gravimetric method. Clay mineralogy data

Table 1. Selected physical and chemical attributes of the soils ${ }^{(1)}$.

\begin{tabular}{|c|c|c|c|c|c|c|c|c|c|c|}
\hline \multirow[t]{2}{*}{ Soil series } & \multirow{2}{*}{$\begin{array}{l}\text { Depth } \\
\text { (cm) }\end{array}$} & \multirow[t]{2}{*}{$\mathrm{pH}$} & \multirow{2}{*}{ OC } & \multirow{2}{*}{$\begin{array}{l}\text { Silt } \\
---(c)\end{array}$} & \multirow[t]{2}{*}{ Clay } & \multirow[t]{2}{*}{ SM } & \multirow{2}{*}{$\begin{array}{c}\text { CEC } \\
\left(\mathrm{cmol}_{\mathrm{c}} \mathrm{kg}^{-1}\right)\end{array}$} & \multicolumn{2}{|c|}{ Clay mineralogy ${ }^{(2)}$} & \multirow[t]{2}{*}{ Soil texture $^{(3)}$} \\
\hline & & & & & & & & Dominant & Other & \\
\hline DRm & $0-15$ & 6.7 & 0.71 & 04 & 22 & 11.0 & 6.98 & $\mathrm{~K}, \mathrm{H}$ & $\mathrm{G}$ & $\mathrm{SC}$ \\
\hline PL & $0-15$ & 5.1 & 1.55 & 13 & 68 & 27.0 & 11.07 & $\mathrm{~K}, \mathrm{H}$ & G & $\mathrm{C}$ \\
\hline $\mathrm{HG}$ & $0-15$ & 4.1 & 5.06 & 45 & 44 & 43.6 & 21.83 & na & na & SCL \\
\hline THx1 & $0-15$ & 5.8 & 2.29 & 18 & 73 & 33.9 & 9.16 & $\mathrm{~K}, \mathrm{H}$ & G & $\mathrm{C}$ \\
\hline THx2 & $15-30$ & 5.4 & 1.73 & 14 & 77 & 34.0 & 8.08 & $\mathrm{~K}, \mathrm{H}$ & G & $\mathrm{C}$ \\
\hline THх3 & $30-45$ & 5.0 & 1.47 & 10 & 81 & 34.0 & 8.58 & $\mathrm{~K}, \mathrm{H}$ & G & $\mathrm{C}$ \\
\hline THx4 & $45-60$ & 5.2 & 1.43 & 03 & 87 & 33.4 & 7.34 & $\mathrm{~K}, \mathrm{H}$ & G & $\mathrm{C}$ \\
\hline THx5 & $60-75$ & 5.1 & 1.05 & 07 & 83 & 32.1 & 7.23 & $\mathrm{~K}, \mathrm{H}$ & G & $\mathrm{C}$ \\
\hline ТНх6 & $75-90$ & 5.1 & 1.03 & 14 & 77 & 31.4 & 6.87 & $\mathrm{~K}, \mathrm{H}$ & G & $\mathrm{C}$ \\
\hline THx7 & $90-105$ & 5.2 & 0.95 & 09 & 81 & 31.3 & 6.52 & $\mathrm{~K}, \mathrm{H}$ & G & $\mathrm{C}$ \\
\hline THх8 & $105-120$ & 5.1 & 1.02 & 03 & 87 & 31.5 & 6.36 & $\mathrm{~K}, \mathrm{G}$ & $\mathrm{H}$ & $\mathrm{C}$ \\
\hline
\end{tabular}

1)OC: organic carbon content; SM: soil moisture (w/w) at 0.3 bar; CEC: cation exchange capacity. (2)K: kaolinite; G: gibbsite; H: hematite; na: data not available. ${ }^{(3)}$ SC: silty clay; SCL: sandy clay loam; C: clay. 
was adapted from Sans (1986) for THx soil sample, and from Silva et al. (1996) for DRm and PL soils.

Technical grade imazaquin $(99.6 \% \mathrm{w} / \mathrm{w}$ pure, supplied by Brazilian Cyanamid) was used without further purification. Fresh imazaquin stock solutions were prepared for each experiment, by dissolving herbicide overnight in $0.01 \mathrm{M} \mathrm{CaCl}_{2}$ solution. All the analytical procedure was accomplished at room temperature $\left(27 \pm 1^{\circ} \mathrm{C}\right)$.

To determine equilibration time, $10 \mathrm{~mL}$ of imazaquin $4 \mathrm{mg} \mathrm{L}^{-1}$ solution were added to $10 \mathrm{~g}$ of soil in $60 \mathrm{~mL}$ centrifuge tubes and shaken at room temperature. The supernatant was removed from each tube after 1, 5, 9, 24 and 48 hours of soil-solution contact. The supernatant was centrifuged for 10 minutes at 2,200 rpm (921.53 g), and stored in freezer $\left(-15^{\circ} \mathrm{C}\right)$ until analysis. All samples were run in duplicates. Equilibration time was stablished as the necessary time for the herbicide concentration remains constant for 34 hours (Ibama, 1996).

Herbicide concentration in solution was determined by HPLC. Solutions were analyzed directly by injecting $100 \mu \mathrm{L}$ of imazaquin solution into a $15 \mathrm{~cm}$ by $4.6 \mathrm{~mm}$ ODS Adsorbosil $\mathrm{C}_{18}$ column. Isocratic elutions were

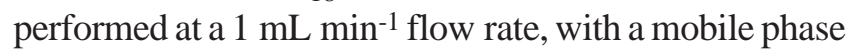
of $50 \%$ acetonitrile, in water at $\mathrm{pH} 3$ (calibrated with $0.04 \%$ phosphoric acid), and detected at $240 \mathrm{~nm}$ wavelenght. Peak area was used for residue quantification. The amount of imazaquin sorbed to soil was calculated from the difference between the initial and remaining concentration in solution after equilibration.

Sorption coefficients were measured in seven imazaquin concentrations for each isotherm at a 1:1 soil:solution ratio for DRm, PL, THx and 1:8 soil: solution ratio for HG. Therefore, $10 \mathrm{~g}$ of the soils DRm, PL, THx and $1.25 \mathrm{~g}$ of the soil HG were placed in $60-\mathrm{mL}$ centrifuge tubes. Ten millilitres of $0.01 \mathrm{M} \mathrm{CaCl}_{2}$ solution were added to the tubes containing imazaquin at concentrations of $0,0.3,0.6,1,1.3,1.6$ and $2 \mathrm{mg} \mathrm{L}^{-1}$ in DRm and PL soils, and 0, 0.5, 1, 1.5, 2, 3 and $4 \mathrm{mg} \mathrm{L}^{-1}$ for HG and THx soils. Higher concentrations were used in this study to facilitate imazaquin detection in desorption experiments. The soil:solution ratio was chosen from previous experiments, which stablished the ratios that would permit that not less than $20 \%$ or not more than $80 \%$ of the total herbicide applied would sorb to soil in a 24-hour period). Duplicate samples were run for each imazaquin concentration. Tubes were then placed on a shaker (200 rpm for 24 hours), at room temperature $\left(26 \pm 1^{\circ} \mathrm{C}\right)$.
After equilibration, tubes were centrifuged at 2,200 rpm (921.53 g) for 10 minutes. The supernatant was filtered through a $0.45 \mu \mathrm{m}$ polyvinilidene difluoride (PVDF) membrane filter, to remove any particulate material. Preliminary experiments to test how much of the herbicide can be retained by the filters and glassware showed that sorption was $<1 \%$. The suspensions were analyzed as already described.

Desorption of imazaquin was determined in tubes after sorption analysis. A volume of $0.01 \mathrm{M} \mathrm{CaCl}_{2}$ herbicidefree solution was added to the soil pastes, that remained in tubes after sorption experiments, until complete $10 \mathrm{~mL}$. The suspensions were shaken for 24 hours and centrifuged at 2,200 rpm for 10 minutes. Aliquots of the supernatant were filtered, stored and analyzed as described above. The amount sorbed in the desorption steps was calculated by subtracting the amount of imazaquin in the entrapped solution after sorption experiments, from the solution concentration measured in this step, desorption experiment.

For sorption and desorption procedures, the $\mathrm{pH}$ of the supernatant was measured before the injection of the samples in the HPLC. Sorption and desorption were described by the Freundlich equation (Green \& Karickhoff, 1990) $X=K_{f} C^{1 / n}$, where $X$ is the amount sorbed $\left(\mathrm{mg} \mathrm{kg}^{-1}\right)$, C is the equilibrium concentration $\left(\mathrm{mg} \mathrm{L}^{-1}\right)$, and $\mathrm{K}_{\mathrm{f}}$ and $\mathrm{n}$ are constants. Nonlinear regression was used to fit Freundlich equation to the sorption isotherms with $\mathrm{K}_{\mathrm{f} \text {,ads }}$ and $\mathrm{n}_{\mathrm{ads}}$ (sorption), $\mathrm{K}_{\mathrm{f} \text {,des }}$ and $\mathrm{n}_{\text {des }}$ (desorption) as fitting parameters.

The OC normalized sorption constant $\left(K_{f o c}\right)$ was calculated by normalizing $\mathrm{K}_{\mathrm{f} \text {,ads }}$ to the $\mathrm{OC}$ fraction of each soil sample: $\mathrm{K}_{\mathrm{foc}}=\left(\mathrm{K}_{\mathrm{f}, \text { ads }} / \% \mathrm{OC}\right) 100$.

\section{Results and Discussion}

Preliminary studies demonstrated that equilibration time is to be completed within 24 hours, with no imazaquin degradation occurring over this period (Regitano et al., 1997, 2001). Freundlich parameters adjusted for sorption and desorption of imazaquin are in Table 2. Except for PL soil, all $1 / n$ values for sorption were lower than unity, indicating a nonlinear relationship between imazaquin concentration and its retention in soil.

The values of $\mathrm{K}_{\mathrm{f} \text {,ads }}$ for imazaquin ranged from 0.25 to 11. Regitano et al. (2001) studying the imazaquin sorption on oxisols, with similar physical chemistry properties, found different $K_{f, a d s}$ values ranging from low to moderate ( $\mathrm{K}_{\mathrm{f}} \leq 3$ for most oxisols), except to $\mathrm{HG}$, in 
which $K_{f}$ was 19.29. While these authors used 1:2.5 soilsolution ratio to measure the $\mathrm{K}_{\mathrm{f}}$, for all soils studied in this work a 1:1 soil-solution ratio was used, except for HG. For the HG soil sample, a 1:8 soil-solution ratio was used in this study explaining the lowest value obtained, compared with the $\mathrm{K}_{\mathrm{f}, \text { ads }}$ value obtained by Regitano et al. (2001). Normally, large soil-solution ratio promotes lower herbicide retention compared with the straight ones. Another reason that can explain the highest $\mathrm{K}_{\mathrm{f}}$ values, obtained in this study, can be attributed to the highest clay content in the soils, compared with the ones used by Regitano et al. (2001), especially, for the subsurface soil samples (i.e. THx samples). Except for the HG soil, all the other samples belong to the same soil class having a similar mineralogy and texture (Table 1). From this result, it can be observed that a good comparison between $\mathrm{K}_{\mathrm{f} \text {,ads }}$ values might be done between soils of the same class or the ones having similar mineralogy.

The lowest imazaquin retention for the DRm soil, in both sorption and desorption studies, is due to an accumulative effect of low clay content and high $\mathrm{pH}$. At pH 6.7, approximately $99.8 \%$ of imazaquin molecules are in anionic form (Lee et al., 1990) having repulsion from the soil particles also negatively charged. Rocha et al. (2002) also described very low imazaquin sorption on oxisols having high $\mathrm{pH}$ values, compared with the ones having low $\mathrm{pH}$. In the present study, for the DRm soil sample, the supernatant carted more than $72.4 \%$ of the initial concentration, in all concentrations after the sorption step (Table 3). Data in Table 3 provide evidences that the largest concentration of imazaquin in solution were obtained with the surface soil samples $(0-15 \mathrm{~cm})$, i.e., those with highest $\mathrm{pH}$ values. Smaller amounts of imazaquin in solution were obtained with the subsurface soil samples - THx, where lower $\mathrm{pH}$ values were found.

For PL soil sample, $\mathrm{K}_{\mathrm{f} \text {,ads }}$ value is almost six times higher than that obtained by Regitano et al. (2001), with the same soil. Again, the highest $\mathrm{K}_{\mathrm{f}, \text { ads }}$ value obtained in this study is due to the $1: 1$ soil:solution ratio used. The amount of sorbed imazaquin, which remained in the supernatant after desorption experiment for PL and HG samples, decreased compared with the other soil samples (Table 3). The imazaquin $\mathrm{K}_{\mathrm{f} \text {,des }}$ for PL increased almost 7 times while for HG it decreased almost 50\% (Table 2). This result showed that imazaquin has stronger affinity for the PL sample compared with the HG sample, especially after desorption experiment. Since the HG sample had highest sorption ( $\left.\mathrm{K}_{\mathrm{f} \text {,ads }}\right)$, its desorption seems to be more easily compared with the PL sample. In this situation, it can be expected more imazaquin leaching on the organic soil, compared with the PL soil sample. The strongest imazaquin affinity by the PL sample is due to its highest amount of $\mathrm{Fe}_{2} \mathrm{O}_{3}$ and gibbsite (27.8 and $22.0 \%$ ), compared with other samples, which had almost half amount of these minerals (Oliveira, 1998).

The highest values of $\mathrm{K}_{\mathrm{f} \text {,ads }}$ of imazaquin were obtained in soils with higher clay contents and low $\mathrm{pH}$ value (Table 4), as it was also observed by several authors (Regitano et al., 1997, 2001; Rocha et al., 2002). These two soil properties were related each other which is shown by the negative correlation between $\mathrm{pH}$ and clay

Table 2. Sorption and desorption Freundlich parameters $\left(\mathrm{K}_{\mathrm{f}}, \mathrm{L} \mathrm{kg}^{-1}\right)$, determination coefficients $\left(\mathrm{R}^{2}\right)$ for isotherms, and normalized sorption coefficients for soil organic carbon content $\left(\mathrm{K}_{\mathrm{foc}}\right)$ of imazaquin ${ }^{(1)}$.

\begin{tabular}{|c|c|c|c|c|c|c|c|c|c|c|}
\hline \multirow[t]{2}{*}{ Soil } & \multicolumn{5}{|c|}{ Sorption } & \multicolumn{5}{|c|}{ Desorption } \\
\hline & $\mathrm{pH}_{\mathrm{ads}}$ & $1 / \mathrm{n}_{\mathrm{ads}}$ & $\mathrm{K}_{\mathrm{f}, \mathrm{ads}}$ & $\mathrm{K}_{\mathrm{foc}}$ & $\mathrm{R}^{2}$ & $\mathrm{pH}_{\text {des }}$ & $1 / \mathrm{n}_{\text {des }}$ & $\mathrm{K}_{\mathrm{f}, \mathrm{des}}$ & $\mathrm{R}^{2}$ & $\mathrm{n}_{\mathrm{des}} / \mathrm{n}_{\mathrm{ads}}$ \\
\hline DRm & 6.3 & 0.83 & 0.25 & 35 & 89.4 & 6.5 & 1.09 & 1.99 & 94.9 & 0.76 \\
\hline PL & 4.5 & 1.03 & 3.14 & 203 & 99.6 & 4.3 & 1.29 & 20.47 & 95.9 & 0.80 \\
\hline $\mathrm{HG}$ & 4.5 & 0.83 & 9.25 & 183 & 90.7 & 4.5 & 0.44 & 4.91 & 98.3 & 1.89 \\
\hline THx1 & 4.6 & 0.82 & 5.08 & 222 & 99.8 & 4.6 & 0.78 & 5.87 & 99.6 & 1.05 \\
\hline THx2 & 4.2 & 0.78 & 6.74 & 390 & 99.7 & 4.2 & 0.77 & 7.80 & 99.8 & 1.01 \\
\hline THx 3 & 4.2 & 0.81 & 7.97 & 542 & 98.4 & 4.3 & 0.76 & 8.35 & 97.4 & 1.07 \\
\hline THx4 & 4.2 & 0.93 & 10.22 & 715 & 95.2 & 4.2 & 0.77 & 9.17 & 94.4 & 1.21 \\
\hline THx 5 & 4.3 & 0.82 & 10.01 & 953 & 99.6 & 4.3 & 0.79 & 9.07 & 95.3 & 1.04 \\
\hline THx6 & 4.3 & 0.87 & 8.94 & 868 & 98.6 & 4.3 & 0.81 & 9.26 & 98.6 & 1.07 \\
\hline THx7 & 4.3 & 0.51 & 5.30 & 558 & 96.6 & 4.3 & 0.74 & 9.84 & 99.9 & 0.69 \\
\hline THx8 & 4.3 & 0.87 & 11.00 & 1078 & 97.2 & 4.2 & 0.66 & 9.30 & 99.8 & 1.32 \\
\hline
\end{tabular}

${ }^{(1)} \mathrm{pH}_{\mathrm{ads}}$ and $\mathrm{pH}_{\mathrm{des}}: \mathrm{pH}$ of supernatant after sorption and desorption experiments, respectively; $1 / \mathrm{n}_{\mathrm{ads}}$ : measure of isotherm linearity; $\mathrm{K}_{\mathrm{f}, \text { ads }}$ : Freundlich sorption coefficient; $\mathrm{K}_{\mathrm{foc}}$ : organic carbon coefficient; $\mathrm{R}^{2}$ : square fitting. 
content (Table 4). Generally, the $\mathrm{pH}$ value of the THx subsurface samples were low, compared with the other surface samples. At this $\mathrm{pH}$ value range (from 4.2 to 4.6 ), approximately, 71 to $86 \%$ of imazaquin molecules are in anionic form (Lee et al., 1990). At this $\mathrm{pH}$ range (Table 2) these soils samples, mainly constituted of iron and aluminum oxides, may have developped a net negative charge because their point of zero salt effects (PZSE) are around 3.1 (Hyun et al., 2003). Therefore, cationic connections can be expected between the anionic herbicide and the positive sites of the oxides, as described by Rocha et al. (2002). Such influence of iron and aluminum oxides has also been shown for other ionic compounds, such as 2,4,5- $\mathrm{T}$ and imazaquin (Regitano et al., 1997, 2001), pentachlorophenol (Hyun et al., 2003) and prosulfuron (Hyun \& Lee, 2004). Besides, this high retention of imazaquin can also be explained by the narrow soil: solution relationship adopted in this study (Koskinen \& Cheng, 1983). Moreover, as pH decreases, the amount of imazaquin neutral species increases, and consequently, sorption is also expected to increase, due to hydrophobic interactions with soil organic matter, as observed by Regitano et al. (1997, 2001), or interactions with siloxane surfaces on the clay minerals (Regitano et al., 2001; Johnston et al., 2001, 2002).

Oliveira Junior et al. (1999) studying imazethapyr sorption proposed that the higher sorption of this herbicide, in more acidic conditions, could be an effect of its water solubility reduction, once the herbicide partition in organic surfaces is usually inversely correlated to $\mathrm{K}_{\mathrm{ow}}$ coefficient. However, even the $\mathrm{pH}$ has indicated possibly interaction between imazaquin and organic carbon in a neutral condition, no significant correlation was found between these two parameters, neither for surface nor subsurface soils (Table 4).

The organic carbon content and the CEC of the THx samples increased the amount of imazaquin in solution on the sorption step (Table 4), indicating that around $\mathrm{pH} 4.3$ (pH level of those samples), both the herbicide molecules and organic carbon were in anionic form. Although the $\mathrm{pH}$ of these samples had shown similar values, no significant correlation between imazaquin sorption and $\mathrm{pH}$ can be observed (Table 4). In this situation, the amount of imazaquin sorbed can be described as a reaction of organic carbon, with polivalent cations forming chelates or ionic bridges with acid herbicides, decreasing the pH effect (Renner et al., 1988). These results indicated that the nature of the organic carbon (i.e. degree of degradation, acidity) in the oxisol might play an important role on pesticides sorption.

As well as clay content, moisture content showed a positive and significant correlation with values of $\mathrm{K}_{\mathrm{f} \text {,ads }}$ of imazaquin (Table 3). The increasing imazaquin retention with increases in moisture content can be attributed to the hydration of clay/iron oxides under low $\mathrm{pH}$. In these conditions, kaolinite and oxides link to water molecules forming an eletropositive surface (for instance, iron oxides as $\mathrm{FeOH}_{2}{ }^{+}$) (Koskinen \& Harper, 1990; Schwarzenabach et al., 1992), which leads to higher sorption of the herbicide (Regitano et al., 2001, 2002). Baughman \& Shaw (1996) also verified high retention of imazaquin, under high soil moisture conditions, especially in the $\mathrm{pH}$ range from 3 to 8 , and concluded that this could be an important factor controlling its sorption in soil.

Table 3. Percentages of the initial concentration of imazaquin remained in solution after sorption step, and average percentage of the sorbed concentration remained in solution after desorption steps $\left(\mathrm{C}_{\mathrm{des}}\right)$.

\begin{tabular}{|c|c|c|c|c|c|c|c|c|c|c|c|}
\hline \multirow{2}{*}{$\begin{array}{l}\text { IC imazaquin } \\
\left(\mathrm{mg} \mathrm{L}^{-1}\right)\end{array}$} & \multicolumn{11}{|c|}{ Soil } \\
\hline & $\mathrm{DRm}$ & $\mathrm{PL}$ & $\mathrm{HG}$ & THx 1 & THx2 & THx3 & $\mathrm{THx} 4$ & THx5 & THx6 & THx 7 & THx8 \\
\hline 0.3 & 80.3 & 25.9 & - & - & - & - & - & - & - & - & - \\
\hline 0.5 & - & - & 38.0 & 10.9 & 0.0 & 6.3 & 7.5 & 5.1 & 7.5 & 1.6 & 5.7 \\
\hline 0.6 & 72.4 & 24.0 & - & - & - & - & - & - & - & - & - \\
\hline 1.0 & 78.4 & 25.1 & 41.5 & 11.6 & 8.0 & 6.4 & 6.6 & 5.7 & 6.9 & 4.7 & 6.2 \\
\hline 1.3 & 77.2 & 25.5 & - & - & - & - & - & - & - & - & - \\
\hline 1.5 & - & - & 50.8 & 12.4 & 8.2 & 7.9 & 8.0 & 6.1 & 7.5 & 6.2 & 5.1 \\
\hline 1.6 & 83.2 & 23.5 & - & - & - & - & - & - & - & - & - \\
\hline 2.0 & 83.0 & 24.9 & 58.5 & 12.9 & 8.9 & 8.6 & 8.4 & 6.2 & 7.5 & 6.2 & 6.4 \\
\hline 3.0 & - & - & 47.7 & 14.7 & 10.4 & 10.1 & 7.7 & 6.7 & 8.1 & 7.3 & 7.4 \\
\hline 4.0 & - & - & 46.3 & 15.8 & 11.1 & 8.1 & 5.5 & 8.1 & 10.1 & nd & nd \\
\hline Average & 79.7 & 24.8 & 47.1 & 13.1 & 7.8 & 7.9 & 7.3 & 6.3 & 7.9 & 5.2 & 6.2 \\
\hline $\mathrm{C}_{\mathrm{des}}$ & 81.7 & 10.9 & 8.1 & 11.0 & 7.6 & 6.8 & 5.8 & 6.6 & 6.9 & 4.9 & 5.6 \\
\hline
\end{tabular}

${ }^{(1)}$ Initial concentration of imazaquin. ${ }^{\text {nd }}$ Concentration not detected. 
The values of $\mathrm{K}_{\mathrm{f} \text {,ads }}$ of imazaquin (Table 2), in general, increased with sampling depth, following a similar pattern as compared to clay content variation in THx soil profile (Table 1). The correlation analysis between $K_{f \text {,ads }}$ and soil properties accomplished only with these samples was positive for clay content $(r=0.77)$, and negative for the silt content $(r=-0.75)$, both at $\mathrm{p}<0.05$ (Table 4). For this oxisols, silt particles are very stable microagregates between clay and sand fraction that are not totally destroyed during the fractionation process. Since these particles had no charge, it is expected that they had no effect on imazaquin sorption.

The increasing imazaquin affinity by the soils during desorption step $\left(\mathrm{K}_{\mathrm{f}, \mathrm{des}}\right)$ demonstrated that imazaquin had low desorption (Table 2). This can be better evidenced by the average percentage of imazaquin in solution after desorption (Table 3). Except for DRm, less than $11 \%$ of imazaquin sorbed concentration remained in solution, after desorption steps. Comparing the average of imazaquin concentration in solution, the amount of herbicide in solution was more intensively reduced after desorption step than after sorption with the time of

Table 4. Pearson correlation (r) matrix between imazaquin sorption parameters and organic carbon content (OC), silt, clay, cations exchange capacity (CEC), soil moisture and $\mathrm{pH}$.

\begin{tabular}{|c|c|c|c|c|c|c|}
\hline Parameter & OC & $\begin{array}{c}\text { Silt } \\
--(\%)\end{array}$ & Clay & $\begin{array}{c}\text { CEC } \\
\left(\mathrm{cmol}_{\mathrm{c}} \mathrm{kg}\right.\end{array}$ & $\begin{array}{l}\text { SM } \\
(w / w\end{array}$ & $\mathrm{pH}^{(1)}$ \\
\hline & \multicolumn{6}{|c|}{ All surface soil samples } \\
\hline $\mathrm{K}_{\text {f.ads }}$ & 0.20 & 0.10 & $0.64^{*}$ & 0.09 & $0.72^{*}$ & $-0.70^{*}$ \\
\hline$\%$ Solution ${ }^{(2)}$ & 0.25 & 0.26 & $-0.99^{*}$ & 0.38 & -0.56 & $0.93^{*}$ \\
\hline $1 / \mathrm{n}_{\mathrm{ads}}$ & 0.09 & -0.01 & -0.08 & 0.17 & -0.09 & 0.05 \\
\hline $\mathrm{K}_{\mathrm{foc}}$ & -0.42 & -0.44 & $0.74^{*}$ & -0.47 & 0.25 & -0.58 \\
\hline $\mathrm{pH}_{\mathrm{ads}}$ & -0.07 & -0.05 & $-0.90^{*}$ & 0.04 & $-0.78^{*}$ & $0.99^{*}$ \\
\hline $\mathrm{K}_{\text {f.des }}$ & -0.21 & -0.17 & 0.45 & -0.08 & 0.08 & -0.54 \\
\hline $1 / \mathrm{n}_{\text {des }}$ & -0.54 & -0.47 & -0.23 & -0.37 & $-0.75^{*}$ & 0.39 \\
\hline \multirow[t]{2}{*}{$\mathrm{C}_{\text {desorbed }}$} & -0.23 & -0.21 & $-0.83^{*}$ & -0.12 & $-0.86^{*}$ & $0.99^{*}$ \\
\hline & \multicolumn{6}{|c|}{ Profile THx only $(0-120 \mathrm{~cm})$} \\
\hline $\mathrm{K}_{\text {f.ads }}$ & -0.53 & $-0.75^{*}$ & $0.77^{*}$ & -0.50 & -0.29 & -0.42 \\
\hline$\%$ Solution & $0.89^{*}$ & $0.72^{*}$ & $-0.71^{*}$ & $0.82^{*}$ & 0.59 & 0.66 \\
\hline $1 / \mathrm{n}_{\mathrm{ads}}$ & 0.21 & -0.17 & 0.20 & 0.19 & 0.29 & -0.09 \\
\hline $\mathrm{K}_{\mathrm{foc}}$ & $-0.82^{*}$ & $-0.71^{*}$ & $0.71^{*}$ & $-0.79^{*}$ & -0.70 & -0.27 \\
\hline $\mathrm{pH}_{\mathrm{ads}}$ & 0.41 & 0.50 & $-0.53^{*}$ & 0.26 & -0.11 & $0.88^{*}$ \\
\hline $\mathrm{K}_{\text {f.des }}$ & $-0.96^{*}$ & $-0.71^{*}$ & $0.71^{*}$ & $-0.89^{*}$ & $-0.72^{*}$ & $-0.75^{*}$ \\
\hline $1 / n_{\text {des }}$ & 0.27 & 0.56 & -0.56 & 0.41 & 0.26 & 0.34 \\
\hline $\mathrm{C}_{\text {desorbed }}$ & $0.88^{*}$ & $0.78^{*}$ & $-0.78^{*}$ & $0.82^{*}$ & 0.57 & $0.82^{*}$ \\
\hline
\end{tabular}

${ }^{(1)} \mathrm{pH}$ of supernatant after sorption or desorption experiments. (2)Percentage of imazaquin concentration in solution. *Significant at 5\% probability level. agitation. This tendency was not observed for the subsurface samples. Presumably, the processes and forces of imazaquin sorption in soil tended to remain constant or to increase with time of shaking, except for DRm subsurface soil samples. For the THx subsurface samples, the similar amount of imazaquin in solution was found after sorption and desorption step (Table 3), characterized by the increasing of correlation value between OC and $\mathrm{K}_{\mathrm{f} \text {,ads }}$ and OC and $\mathrm{K}_{\mathrm{f} \text {,des }}$ (Table 4), consecutively, such amount can be explained by the increasing of the soluble OC content in solution, after desorption step. At the $\mathrm{pH}$ level of this sample, the OC might have a negative charge, as imazaquin as well. The increasing tendecy of $\mathrm{pH}$ with increasing of OC content, for the subsurface samples (Table 4), showed that OC is playing role as a buffer in the supernatant, capturing $\mathrm{H}^{+}$and raising the $\mathrm{pH}$, which shows the negative nature of the OC.

In PL soil, the concentration of imazaquin remained in solution, after sorption, was constant in all concentrations (Table 3), demonstrating that the sorbed concentration is directly proportional to the amount of the herbicide in solution $\left(1 / \mathrm{n}_{\mathrm{ads}} \sim 1,0\right)$ (Table 2$)$, and that the imazaquin capacity of retention by soil was not saturated. That fact can be further explained by $\mathrm{K}_{\mathrm{f} \text {,des }}$ value, which was six times higher in relation to $\mathrm{K}_{\mathrm{f} \text {,ads }}$ value (Table 2), showing high imazaquin interaction with this soil. Except for the PL soil, all of the $1 / n_{\text {ads }}$ values were lower than unity, indicating a nonlinear relationship between concentration of imazaquin and its retention in soil.

\section{Conclusions}

1. The clay content and $\mathrm{pH}$ values are the main soil properties controlling the imazaquin sorption on these soils.

2. The clay content and $\mathrm{pH}$ values have a positive and negative correlation, respectively, with imazaquin $\mathrm{K}_{\mathrm{f} \text {,ads }}$, but the correlation analysis between $\mathrm{K}_{\mathrm{f} \text {,ads }}$ and soil properties should only be accomplished for soils of the same class.

3 . The clay content and $\mathrm{pH}$ values have bigger influence on imazaquin sorption than organic carbon content for these tropical soils.

4. For samples of the profile of THx, soil water content presents a positive correlation with imazaquin $\mathrm{K}_{\mathrm{f}, \text { ads }}$ and the sorption increases with depth of sampling. 


\section{Acknowledgements}

To Uenf, Embrapa Milho e Sorgo and Fapemig, for the financial support; to Brazilian Cyanamid for the technical imazaquin; to Mr. Nilson M. Lopes, Embrapa's technician, for HPLC help; to undergraduate students Tricia C. L. de Faria, Gibson A. S. Soares and Roqueline R. Silva, for their collaboration to this work.

\section{References}

ALLEONI, L.R.F.; CAMARGO, O.A. Solos ácricos: atributos e manejo. Boletim Informativo da Sociedade Brasileira de Ciência do Solo, v.20, p.9-17, 1995.

BAUGHMAN, T.A.; SHAW, D.R. Effect of wetting drying cycles on dissipation patterns of bioavailable imazaquin. Weed Science, v.44, p.380-382, 1996.

FELDING, G. Pesticide adsorption as a function of depth below surface. Pesticide Science, v.50, p.64-66, 1997.

GEE, G.W.; BAUDER, J.W. Particle-size analysis. In: KLUTE, A. (Ed.). Methods of soil analysis: physical and mineralogical methods, part 1. 2.ed. Madison: American Society of Agronomy, Soil Science Society of America, 1986. p.383-411. (Agronomy series, 9).

GREEN, R.E.; KARICKHOFF, S.W. Sorption estimates for modeling. In: CHENG, H.H. (Ed.). Pesticides in the soil environment: processes, impacts and modeling. Madison: Soil Science Society of America, 1990. p.79-101.

HYUN, S.; LEE, L.S. Factors controlling sorption of prosulfuron by variable-charge soils and model sorbents. Journal of Environmental Quality, v.33, p.1354-1361, 2004.

HYUN, S.; LEE, L.S.; RAO, P.S.C. Significance of anion exchange in pentachlorophenol sorption by variable-charge soils. Journal of Environmental Quality, v.32, p.966-976, 2003.

IBAMA. Manual de testes para avaliação da ecotoxicidade de agentes químicos. 2.ed. Brasília, DF, 1996.

INOUE, M.H. Potencial de lixiviação de herbicidas e dinâmica de atrazine e diuron em uma litoseqüência do Estado do Paraná. 2002. 68p. Dissertação (Mestrado) - Universidade Estadual de Maringá, Maringá.

JENKS, B.M.; ROETH, F.W.; MARTIN, A.R.; McCALLISTER, D.L. Influence of surface and subsurface soil properties on atrazine sorption and degradation. Weed Science, v.46, p.132-138, 1998.

JOHNSTON, C.T.; OLIVEIRA, M.F. de; TEPPEN, B.J.; SHENG, G.; BOYD, S.A. Spectroscopic study of nitroaromatic - smectite sorption mechanisms. Environmental Science and Technology, v.35, p.4767-4772, 2001.

JOHNSTON, C.T.; SHENG, G.; TEPPEN, B.J.; BOYD, S.A.; OLIVEIRA, M.F. de. Spectroscopic study of dinitrophenol herbicide sorption on smectite. Environmental Science and Technology, v.36, p.5067-5074, 2002.
KOSKINEN, W.C.; CHENG, H.H. Effects of experimental variables on 2,4,5-T adsorption-desorption in soil. Journal of Environmental Quality, v.12, p.325-330, 1983.

KOSKINEN, W.C.; HARPER, S.S. The retention process: mechanisms. In: CHENG, H.H.; BAILEY, G.W.; GREEN, R.E.; SPENCER, W.F. (Ed.). Pesticides in the soil environment: processes, impacts, and modeling. Madison: Soil Science Society of America, 1990. p.51-77.

LEE, L.S.; RAO, P.S.C.; NKEDI-KIZZA, P.; DELFINO, J.J. Influence of solvent and sorbent characteristics on distribution of pentachlorophenol in octanol-water and soil-water systems. Environmental Science and Technology, v.24, p.654-661, 1990.

NELSON, D.W.; SOMMERS, L.E. Total carbon, organic carbon, and organic matter. In: PAGE, A.L.; MILLERR, H.; KEENEY, D.R. (Ed.). Methods of soil analysis: chemical and microbiological properties, part 2. $2^{\text {nd }}$ ed. Madison: Soil Science Society of America, 1982. p.539-577. (Agronomy series, 9).

OLIVEIRA, M.F. de. Retenção dos herbicidas flazasulfuron e imazaquin em solos de diferentes classes e hidrólise do flazasulfuron em diferentes valores de pH e temperatura. 1998. 71p. Tese (Doutorado) - Universidade Estadual do Norte Fluminense, Campos dos Goytacazes, RJ.

OLIVEIRA JUNIOR, R.S.; KOSKINEN, W.C.; FERREIRA, F.A. Sorption and leaching potential of herbicides on Brazilian soils. Weed Research, v.41, p.97-110, 2001.

OLIVEIRA JUNIOR, R.S.; KOSKINEN, W.C.; FERREIRA, F.A.; KHAKURAL, B.R.; MULLA, D.J.; ROBERT, P.J. Spatial variability of imazethapyr sorption in soil. Weed Science, v.47, p.243-248, 1999.

RACKE, K.D.; SKIDMORE, M.W.; HAMILTON, D.J.; UNSWORTH, J.B.; MIYAMOTO, J.; COHEN, S.Z. Pesticides report 38. Pesticide fate in tropical soils: technical report. Pure and Applied Chemistry, v.69, p.1349-1371, 1997.

REGITANO, J.B.; ALLEONI, L.R.F.; TORNISIELO, V.L. Atributos de solos tropicais e a sorção de imazaquin. Scientia Agricola, v.58, p.801-807, 2001.

REGITANO, J.B.; BISCHOFF, M.; LEE, L.S.; REICHERT, J.M.; TURCO, R.F. Retention of imazaquin in soil. Environmental Toxicology and Chemistry, v.16, p.397-404, 1997.

REGITANO, J.B.; PRATA, F.; ROCHA, W.S.D.; TORNISIELO, V.L.; LAVORENTI, A. Imazaquin mobility in tropical soils in relation to soil moisture and rainfall timing. Weed Research, v.42, p.271279, 2002.

RENNER, K.A.; MEGGITT, W.F.; PENNER, D. Effect of soil pH on imazaquin and imazethapyr adsorption to soil and phytotoxicity to corn (Zea mays). Weed Science, v.36, p.78-83, 1988.

ROCHA, W.S.D.; ALLEONI, L.R.F.; REGITANO, J.B. Energia livre da sorção de imazaquin em solos ácricos. Revista Brasileira de Ciência do Solo, v.27, p.239-246, 2003.

ROCHA, W.S.D.; REGITANO, J.B.; ALLEONI, R.L.F.; TORNISIELO, V.L. Sorption of imazaquin in soils with positive balance of charges. Chemosphere, v.49, p.263-270, 2002.

SANS, L.M.A. Estimativa do regime de umidade, pelo método de Newhall, de um Latossolo Vermelho-Escuro álico da região 
de Sete Lagoas, MG. 1986. 190p. Tese (Doutorado) - Universidade Federal de Viçosa, Viçosa.

SILVA, M.L.N.; CURI, N.; MARQUES, J.J.G.S.M.; GUILHERME, L.R.G.; LIMA, J.M. Ponto de efeito salino nulo e suas relações com propriedades mineralógicas e químicas de latossolos brasileiros. Pesquisa Agropecuária Brasileira, v.31, p.663-671, 1996.

SCHWARZENBACH, R.P.; GSCHWEND, P.M.; IMBODEN, D.M. (Ed.). Environmental organic chemistry. New York: J. Wiley \& Sons, 1992. 657p.

Received on February 4, 2004 and accepted on July 18, 2005 